\title{
Materials and Installation of Delivery Pipes for Irrigation Systems $^{1}$
}

Brian Boman and Sanjay Shukla ${ }^{2}$

\section{Introduction}

Main considerations for the choice of materials in an irrigation system are the ability of the material to withstand mechanical stresses, extreme temperatures, solar radiation, and chemical contacts to which they may be subjected. Mechanical stress may be due to internal conditions such as water pressure, water acidity and alkalinity, water hammer, and vacuum. Components may also be affected by such external forces as earth load, thermal expansion and contraction, and mechanical blows to the component. There are numerous combinations of metals, composites, plastics, ceramics, and elastomers that can be used in components for an irrigation system. Not only should the materials be able to withstand the mechanical and environmental stresses that may occur, but they should be compatible with each other to avoid internal corrosion or galvanic effects. The main considerations in component selection are pressure rating, temperature range, chemical affinity, and cost.
The design working pressure is the most important factor in selecting materials for the water distribution system. Typically, pipelines and control devices should be able to withstand twice the normal operating pressure. For instance, if the maximum normal operating pressure is $50 \mathrm{psi}$, all components should be able to withstand a surge of $100 \mathrm{psi}$.

The ambient and water temperatures should receive some consideration in the selection of construction materials. High temperatures may decrease the strength of plastics. In cases where components may be exposed to high temperatures (e.g. around pump stations), special high-temperature plastics or steel should be used instead of PVC. In areas subject to freezing, consideration should be given to materials that will not fracture as easily as cast iron. Ultraviolet (UV) radiation is a common problem for applications exposed to sunlight. UV radiation may cause degradation of most plastics; therefore, additives such as carbon black are used to inhibit this process. Elastomers are normally less influenced by UV radiation, and metals are usually unaffected.

1. This document, Cir 1424, is one of a series of the Agricultural and Biological Engineering Department, Florida Cooperative Extension Service, Institute of Food and Agricultural Sciences, University of Florida. Original publication date February 2001. Visit the EDIS Web Site at http://edis.ifas.ufl.edu.

2. B. J. Boman, Associate Professor, University of Florida, Indian River Research and Education Center, Ft. Pierce; and Sanjay Shukla, Assistant Professor, University of Florida, Southwest Florida Research and Education Center, Immokalee. Cooperative Extension Service, Institute of Food and Agricultural Sciences, Gainesville, FL 32611.

The Institute of Food and Agricultural Sciences (IFAS) is an Equal Employment Opportunity - Affirmative Action Employer authorized to provide research, educational information and other services only to individuals and institutions that function without regard to race, creed, color, religion, age, disability, sex, sexual orientation, marital status, national origin, political opinions or affiliations. For information on obtaining other extension publications, contact your county Cooperative Extension Service office. Florida Cooperative Extension Service / Institute of Food and Agricultural Sciences / University of Florida / Larry R. Arrington, Interim Dean 
Chemical resistance is an important consideration since microirrigation systems are usually designed with the potential to inject different types of agricultural chemicals ranging from fertilizers to line cleaners. Consequently, unpredictable combinations of often corrosive compounds may travel through the system. Acidic (low $\mathrm{pH}$ ) conditions will result in corrosion of most metals. Aluminum and zinc are the metals most sensitive to acid. Cast iron, carbon steel, and copper alloys are less sensitive, but for a prolonged exposure to acidic conditions, a resistant material such as 316 stainless steel should be considered. High $\mathrm{pH}$ (alkaline) conditions may be harmful to aluminum, zinc, and titanium. Most other metals, as well as most plastics and elastomers, are not sensitive to alkaline conditions.

The effect of dissolved solids in water is to increase the electrical conductivity and acceleration of the corrosion processes. Common cations such as calcium $\left(\mathrm{Ca}^{++}\right)$, potassium $\left(\mathrm{K}^{+}\right)$, and sodium $\left(\mathrm{Na}^{+}\right)$ have almost no effect on most metals and plastics, while ammonium $\left(\mathrm{NH}_{4}\right)$ may attack some plastics and elastomers. Anions such as sulfides and sulfates are much more harmful to both metals and plastics.

Solid particles such as sand in the water stream can result in severe erosion of metal and plastic components. Erosion of surfaces can also result from cavitation. Cast iron, mild steel, and copper alloys can be coated by hard metals or ceramics to make them more resistant to cavitation. Plastics and elastomers are more resilient and resistant to cavitation erosion; however, they are more susceptible to abrasion damage from high-velocity solids.

\section{Ferrous Materials}

Cast iron pipe is generally used for the bodies of most water meters and valves larger than 3 inches. Cast iron is also used for other large components that require economical pricing. For higher pressure applications and severe working conditions, ductile cast iron, cast alloy, or other special metals may be used.

Cast iron normally has a very good resistance to corrosive conditions without any special protection. Coating the bodies with protective paints such as epoxy resins is a common practice. However, under normal operating conditions, unprotected cast iron parts normally do not corrode to the degree which impairs their performance. When exposed to cathodic materials such as copper, cast iron components may develop corroded surfaces. These corroded areas should be periodically removed to prevent impaired function.

Components constructed from steel plate normally have low corrosion resistance. Therefore, these components must be specially coated or galvanized on both the inside and outside. In spite of this protection, serious corrosion may occur to the component if there are copper or copper alloy parts in contact with the steel. Periodic inspection and recoating are necessary to ensure long-term operation. Particular attention should be given to weldings, as they are sensitive to corrosion.

\section{Non-Ferrous Metals}

Bodies of valves smaller than 2 inches and other small components are often constructed from cast bronze. Cast bronze is also used for bodies of larger valves designed for high pressure and for various parts of valve and meter mechanisms. Brass is used for machined parts such as shafts and spindles. Brass inserts are used for bearings and threaded connections in cast iron bodies to reduce friction and avoid corrosion.

Special copper alloys are used for extremely corrosive and erosive conditions, They are also used for applications that have high velocity. Cast aluminum is typically only used in components that are portable or where weight is a serious consideration.

\section{Plastics}

There is a wide array of synthetic resins in the forms of polymers, copolymers, composites, laminates, and coatings. Each of these materials may have different properties. Plastic materials are less resistant to stress than metals and tend to lose strength under pressure and elevated temperatures. They are used for smaller valves and as parts for many devices such as flowmeter impellers, low-friction bushings, and components not subjected to stress. 
Bodies of smaller valves are typically made of glass-reinforced polyester, polyacetal, and polycarbonate. Small mechanisms may be made of an acetal resin such as Delrin. Teflon linings may be used where low friction components are required. Nylon, Teflon, and polyacrilate glass-fiber reinforced materials are often used for flexible small-diameter tubing and joints. Filtering elements often use acetal, polycarbonate resins, thermoplastic polyester, or high density polyethylene. For the protection of metal bodies and component against corrosion, plastic linings and epoxy resins are often used. Valve vanes are often coated with nylon or Teflon to reduce friction.

\section{Elastomers}

Elastomer materials used for gaskets and seals must be able to withstand high stress together with both high and low temperatures. Natural or synthetic rubber has proven to be the most suitable material for gaskets and seals in irrigation systems. They give good performance for resilience, flexibility, and wear. However, they are prone to degradation by microorganisms, especially when in long contact with wet soil. Neoprene reinforced with nylon is generally suitable for flange gaskets. When corrosive materials are present, other hydrocarbon acrylonitrile elastomers such as Buena N, Neoprene, Viton, or EPDM rubber should be used.

\section{PVC Pipe}

Polyvinyl chloride (PVC) pipe is the result of the chemical development of a synthetic base material and is manufactured under computer controlled conditions. It is continuously extruded into seamless lengths which are strong, chemically resistant, have low friction loss, and are lightweight for ease of handling. Type and grade refer to the hydrostatic design stress pressure capabilities of the pipe. Type I, Grade I, is the most commonly used for microirrigation systems. There are both Types I and II and Grades I and II available.

Pressure ratings may be given in feet of head, class or psi rating, schedule, or SDR (Standard Dimension Ratio). PVC pipe may be designated as either low head (pressure), which is rated for less than $50 \mathrm{ft}$ of head (22 psi), or high head which is rated for more than $50 \mathrm{ft}$ of head. Class refers to a pressure rating in pounds per square inch (Table 1). SDR is the ratio of the outside pipe diameter to the wall thickness (Table 1). The operating pressure in use, including surges, must not exceed the class rating. Schedule denotes a plastic pipe which has the same outside diameter and wall thickness as iron or steel pipe of the same nominal size (Table 2). There are pressure rating differences between Types I and II and Grades I and II. This information should be stamped on the pipe. Temperature is also important when using PVC since as the temperature increases, the safe operating pressure decreases (Table 3 ).

To obtain the pressure rating, multiply the pressure rating at $73^{\circ} \mathrm{F}$ by the corresponding service factor (Table 3). Either an IPS or PIP size may be used (Table 4). IPS refers to plastic pipe which has the same outside diameter as iron pipe of the same nominal size. PIP is an industry size designation for plastic irrigation pipe. When obtaining cost estimates, be sure that all estimates are in the same size designation. Normally, pipe size should be large enough so that the water velocity does not exceed 5 feet per second in order to avoid excessive friction losses and surge or water hammer problems. Pipe sections are available in 20-foot, 30-foot, 35-foot, and 40 -foot lengths. Pipes are available in diameters of 4 - 15 inches for low head pipe and 1/2 - 12 inches for high head pipe.

\section{PVC Failure}

Most PVC pipe and fittings used in the irrigation industry are manufactured from Type I, Grade I PVC compounds. These compounds have a minimum tensile strength of 7,000 psi before stress, and a modulus of elasticity $400,000 \mathrm{psi}$ at $73^{\circ} \mathrm{F}$. Even after years of service, PVC pipe normally maintains its ability to withstand occasional high pressure surges. However, if PVC pipe is subjected to frequent pressure variations of a cyclic nature, it can fail, even though the peak pressure never exceeded the design pressure of the pipe. The number of cycles before failure depends on the magnitude of the pressure variation. Usually, the ability of PVC pipe to withstand cyclic pressure conditions is independent of its ability to withstand constant static pressure. 


\section{Burst Failure}

Burst failure in PVC pipe and fittings is usually rather dramatic (Figure 1). It may begin at a point of stress concentration or weakness and continue by splitting through fittings and pipe for some distance. Sometimes, the failures will completely shatter a fitting and the adjacent pipe. Burst failures usually occur during transient hydraulic conditions that create large pressure variations in the system. These include rapid valve closure, pumps starting or stopping, rapid escape of entrapped air, or an air pocket shifting within a pipeline. Burst failure will, sometimes, occur in a pipe or fitting that was damaged during installation or that is subject to external loads. In these cases the failure may occur at pressures well below the expected burst limit of the product.

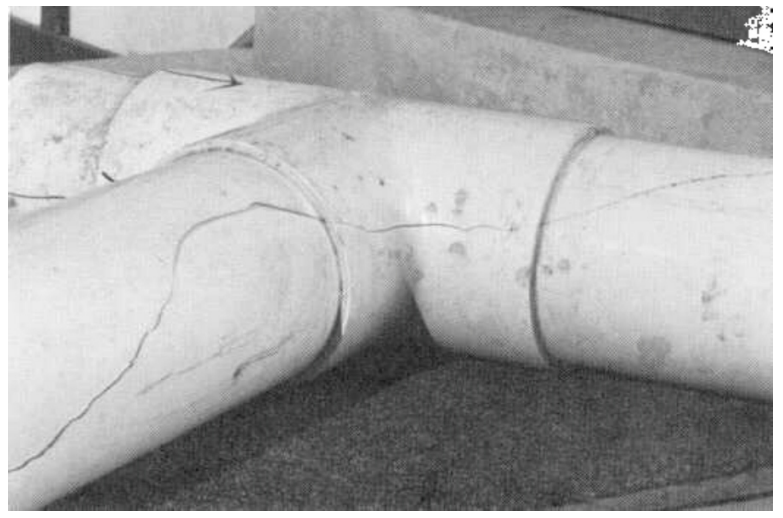

Figure 1. Typical burst failure in PVC pipe (reprinted with permission from Bliesner, 1987).

\section{Long-Term Pressure Failure}

Long-term pressure failure (Figure 2) occurs when the system operates continually at a pressure higher than the pipe rating. The failures can occur within a short time after system installation or after many years. The failures will usually appear as slits or small cracks in the pipe or fitting along the minimum wall thickness or in an area of stress concentration. Some yielding of material will usually be evident.

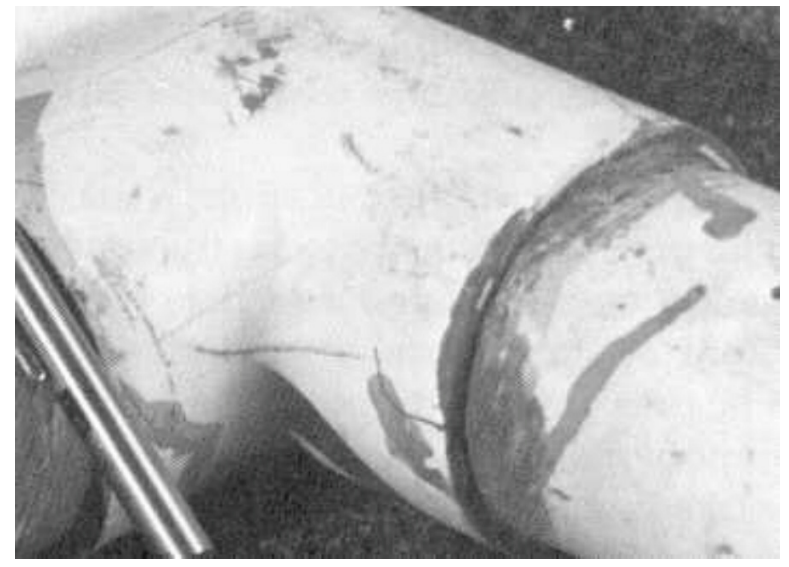

Figure 2. Example of long-term pressure failure in PVC pipe (reprinted with permission from Bliesner, 1987).

\section{Cyclic Surge Failure}

Cyclic surge failure (Figure 3) can occur in systems that are subject to frequent changes in flow and/or pressure. It is difficult to distinguish between cyclic failure and long term static failure in fittings. Due to the stress concentrations and extra forces placed on them, the pipes may not withstand as many cycles even if their burst strength may be equal to that of the same class pipe. There may also be a marked reduction in burst strength after subjection to a period of cyclic pressure appears to be the most critical since fittings are the weakest system components.

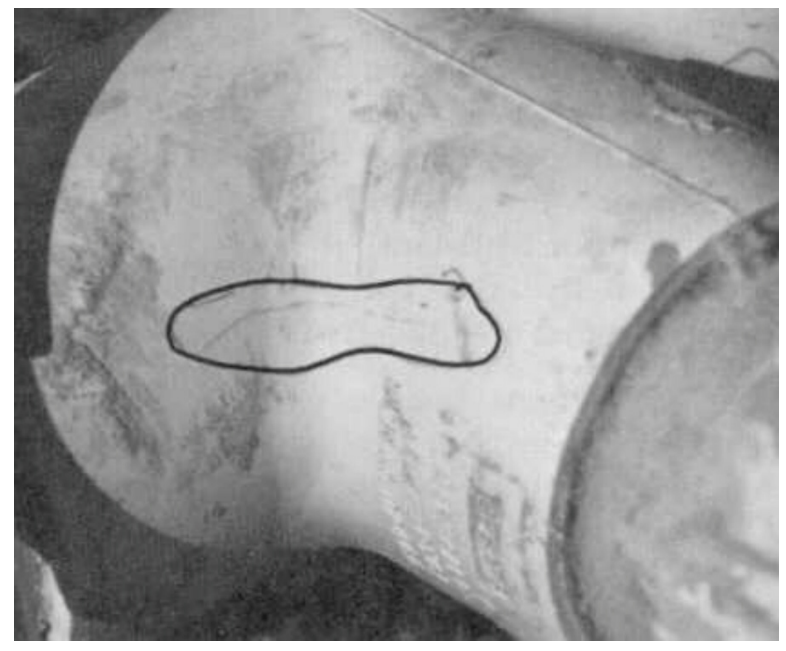

Figure 3. Example of typical cyclic pressure failure in PVC pipe (reprinted from Bliesner, 1987).

\section{Mechanical Failure}

Mechanical failure covers a multitude of piping failures that are unrelated to, but many interact with, the hydraulics of the system. One of the most common types of failure is over-tightening of 
threaded fittings. The threads are smooth and create little friction, and it is easy to over-tighten PVC fittings. It is possible, with little effort, to create circumferential stress beyond the failure limit when assembling threaded fittings. This is even more pronounced when using some thread lubricants, dopes, or sealants. The failure usually appears as a split, perpendicular to the threads, beginning at the leading edge and extending into the body of the fitting (Figure 4). Occasionally, a split at the base of the female threads will appear parallel to the thread direction. This will usually occur in a fitting with a shoulder or thickened place near the base of the threads and is more common when the male part bottoms against a shoulder.

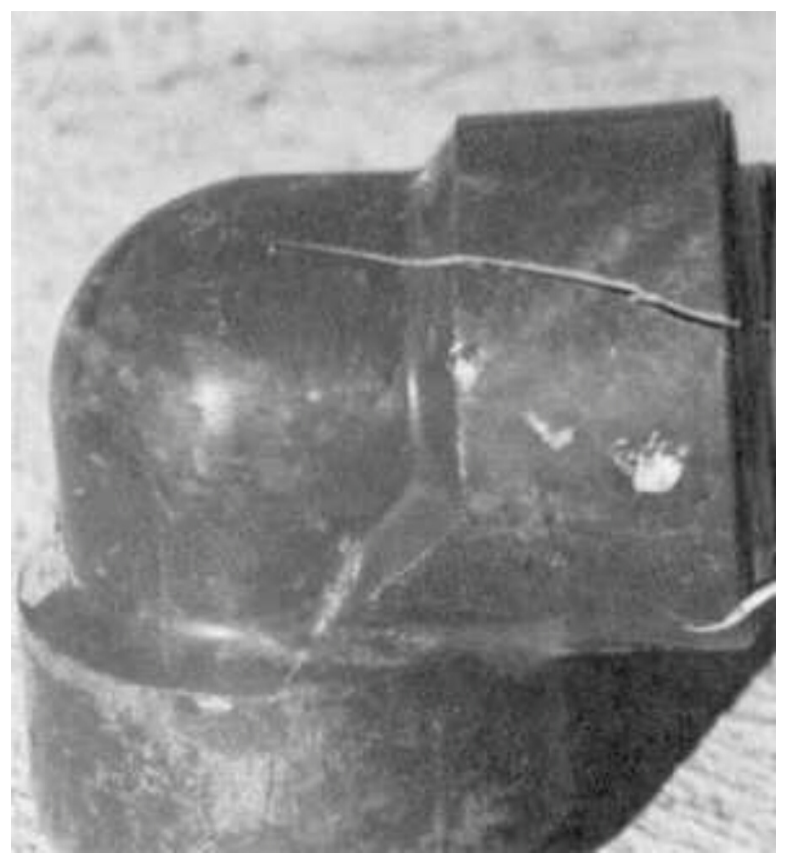

Figure 4. Example of threaded PVC fitting failure due to ever-tightening (reprinted with permission from Bliesner, 1987).

Another type of mechanical failure occurs due to improper solvent welding or improper fitting of the components of an assembly (Figure 5 and Figure 6). Improper penetration of pipe into socketed fittings significantly reduces the strength of the fitting. Improper solvent welding techniques can cause failures in the bonding, creating leaks or separation. Fittings should have full socket penetration in order to avoid significant weakening of the assembly.

Mechanical failure of PVC components can also occur from temperature expansion. If sufficient

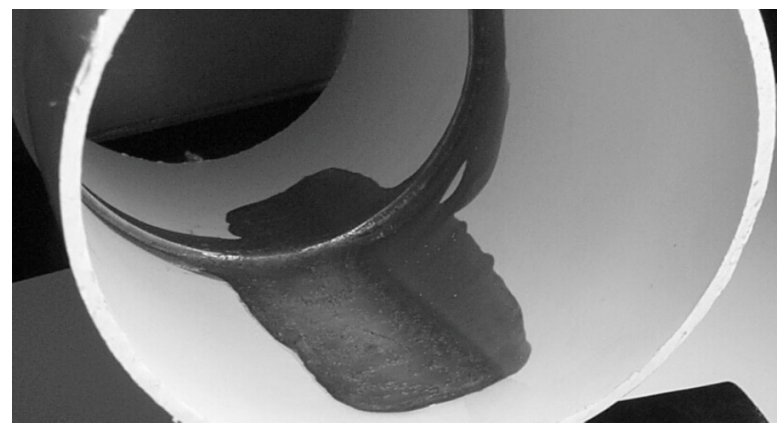

Figure 5. Excess cement used in PVC pipe joint resulting in softened pipe walls.

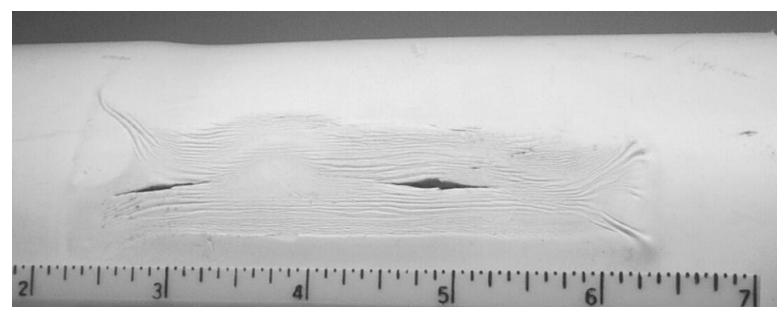

Figure 6. Failure in PVC pipe due to improper solvent welding of joint with excess cement.

expansion allowances are not made by providing expansion loops, offsets, or slip joints, severe stress can be placed on the pipe and fittings. Mechanical failure occurs when inadequate thrust blocking is provided. This allows excessive pressure to be placed on a fitting as the line pressure tries to displace it while the fittings is restrained by the pipe to which it is attached.

\section{Underground Installation, Bedding, and Backfilling}

Both solvent weld and rubber gasket joints are commonly used in irrigation systems. Gasket joints are typically used only in pipe sizes of 10 inches and larger. Rubber gasket joints may be the bell and spigot type, or a separate twin gasket coupler may be used with plain-end pipe. Solvent weld joints are not recommended for operating pressures above $50 \mathrm{psi}$ and pipe diameters above 4 inches. Solvent welding requires extreme cleanliness, and the material has temperature and humidity precautions which must be observed to ensure that it is properly installed.

For buried pipes, the depth of pipe placement should be at least 30 inches below the ground to protect against heavy machinery (Table 5). The trench must be wide enough to ensure proper compacting when a pipeline is buried. This is 
especially important for large diameter pipes. For pipe diameters above 4 inches, a trench at least 12 inches wider than the diameter of the pipe should be specified (ASAE, 1998). Where possible, assemble the pipe above ground and then place it in the trench. If the trench curves, the pipe should be assembled on the outside of the curve to eliminate the possibility of it being too short. A small amount of paint can be sprayed on each joint of gasket pipe before dropping it in the trench. This enables one to see if any joints have slipped apart.

With a smooth, uniform trench bottom, the pipe will be supported over its entire length on firm and stable material. Blocking should never be used to change pipe grade or to provide support over low section(s) in the trench. Because sub-soil conditions can vary greatly within a grove or in various locations, different pipe bedding problems will be encountered. In general, however, sub-soil should be stable and should provide physical protection for the pipe.

The backfill material should have a particle size of $1 / 2$ inch or less. Backfilling should be done in layers with each layer compacted sufficiently to allow uniform development of lateral passive soil forces. For packing the soil, hand tamping or water packing may be used. Hand tamping involves tamping the initial fill in 2-inch layers to at least 6 in. above the pipe to a soil bulk density of at least $85 \%$ of the undisturbed sidewalls. Use water packing only on rapidly draining soils. For the initial coverage of the pipe only fine-grained material free of rocks and clods should be used. If the water packing method is used, the pipeline must be filled with water before beginning the backfilling operation. Backfill approximately 8 inches over the pipe and then add water to thoroughly saturate the initial backfill without over-watering. Close the valves so the pipe remains full and allow the wetted fill to dry until firm before completing the backfill. The pipeline must be full of water to avoid floating the pipe. Always fill low head pipe with water prior to backfilling to avoid damage to the pipe by crushing or flow reduction from flattening.

When compacting sand or gravels, vibratory methods are recommended. If water packing is used, the initial backfill should be sufficient to insure complete coverage of the pipe, and additional backfill should not be added until the water-flooded backfill is firm enough to walk on.

Sand and gravel containing a significant proportion of fine-grained material (silt, clay, etc.) should preferably be compacted by mechanical tamper. If the mechanical tamper is not available, the material should be compacted by hand. In all instances, the trench should be filled completely. All backfill should be placed and spread in fairly uniform layers to eliminate voids or unfilled spaces. Large rocks, clods, and other debris larger than 3 inches in diameter should be removed. Rolling equipment or heavy tampers should be used only to consolidate the final backfill.

\section{Thrust Blocking}

These forces include water under pressure in pipelines exerts thrust forces at tees, elbows, valves, and at any change in pipe size or direction. At times there may be sudden changes in pipeline grade, horizontal alignment of the pipe, or reduction in pipe size. These conditions result in axial thrust and require an anchor or thrust blocks to absorb any axial thrust of the pipeline. Thrust control may also be needed at the end of the pipeline and at in-line control valves. Thrust blocks and anchors must be large enough to withstand the forces that tend to move the pipe. These forces include momentum and pressure as well as forces due to expansion and contraction of pipe. The pipe manufacturer's recommendations for thrust control should be followed. The design of the thrust block also requires information on the magnitude of the thrust generated in the pipeline (Table 6) and the bearing strength of the soil (Table 7).

Concrete thrust blocks (Figure 7) should be installed at each change in direction (tees, elbows), changes in pipe sizes, and at stops or ends to prevent the pipe damage. Each thrust block should be large enough to adequately bear the thrust of water in the pipe, which at times can be as much as 5,000 to 6,000 pounds of pressure. The exact size of thrust blocks must be calculated for each pipe size and soil type. Typically, the thrust block is constructed on the 
outside edge of an elbow and the downstream side of a tee.

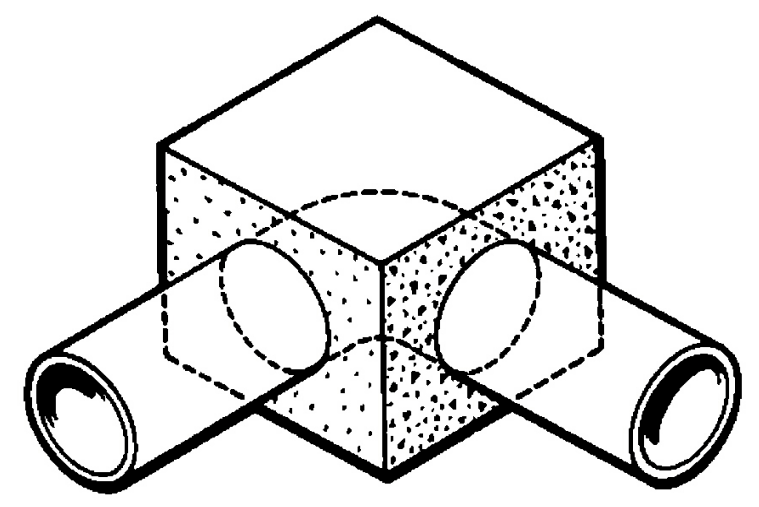

Figure 7. Concrete thrust block used to stabilize corners above and below grade.

\section{Example}

Determine appropriate thrust blocking for a 10 -inch $90^{\circ}$ elbow on a system with a pressure of 50 psi installed in a sandy soil.

From Table 6, the thrust developed by pipeline at $100 \mathrm{psi}$ is $11,200 \mathrm{lb}$. At $50 \mathrm{psi}$, the thrust would be $11,200 \mathrm{lb} \div 2=5,600 \mathrm{lb}$.

From Table 7, the bearing strength for sand is $1,000 \mathrm{lb} / \mathrm{ft}^{2}$. The contact area required to achieve adequate thrust blocking would be: contact area $=$ $5,600 \mathrm{lb} \div 1,000 \mathrm{lb} / \mathrm{ft}^{2}=5.6 \mathrm{ft}^{2}$.

The pipeline should be thoroughly tested for leakage before backfilling operations are undertaken. With gasket joint pipe, it is necessary to partially backfill before testing to hold the line in place. Only body of the pipe should be covered while leaving all the exposed joints. Fill the line very slowly and after filling, increasing to design pressure over a 15 - 20 minute period.

\section{Joining Pipes}

It is essential that fittings, valves, and pipe are of the same type PVC. For example, it is unwise to use Type I and Type II PVC in the same installation. The expansion and contraction features, pressures, etc., are different, and use of mixed materials could cause failure. Make sure that the proper cement is used with the proper PVC pipe and fittings. CPVC Cement on
Type I PVC pipe or, conversely, PVC cement of CPVC pipe and fittings should never be used.

Normally, PVC pipe and fittings are manufactured to produce a snug fit when assembled. The condition, however, can vary because of the minimum and maximum tolerances to which the pipe is produced. In the case of a fitting with the maximum diameter and the pipe with the minimum diameter, a loose fit could result. This can be remedied by interchanging fittings. Application of two coats of solvent cement under these conditions will help assure a good joint. Conversely, if the pipe diameter is on the maximum side and fitting on the minimum side, the interference may be too great. For such cases, sanding may be necessary to make the connection. For these specific reasons, it is important to check the fittings prior to making a solvent-welded joint. The amount of interference and taper on the fitting is greater for Schedule 40 type fittings. The Schedule 40 and lighter-wall SDR pipe have a tendency to round themselves within the Schedule 40 fittings, thus permitting a greater degree of interference. However, in the case of Schedule 80 fittings, the heavy wall on the pipe causes the pipe to be non-roundable. Usually the interference is less on Schedule 80 fittings, which in many cases will allow the pipe to bottom dry with very little interference. It is under these conditions that it may be necessary to apply more than one coat of solvent cement to the pipe and fitting if the "dry fit" seems loose.

The adhesive cement used for PVC bonds is a solvent-based type. The solvent tehtrahydrofuran (THF) dissolves the mating surfaces when properly applied to each surface. The pipes to be bounded should be dry and free from grease and dust. The PVC resin filler contained in the cement assists in filling the gaps between pipe and fitting surfaces. The adhesive cement also contains an evaporation retardant, usually cyclohexanone, which slows the rate of evaporation of the prime solvent. Some of the available cements are clear, while most others contain pigments to match the pipe color. The most common color is grey, made from titanium dioxide and carbon black, which are considered inert pigments.

Joining of the wet mating surfaces in one minute or less after starting to cement is essential to 
eliminate dry non-bonded spots. The bond interface consists of a mixture of cement resin and dissolved PVC from the pipe and fitting surfaces. As the solvent evaporates, the interface becomes homogeneous with the pipe and fitting surfaces, except for residual solvent, which dissipates over a period of a year or longer. The resultant homogeneous bonding has led to term "solvent welded," although no heat is applied to melt and fuse the bonded areas as in metal welding.

\section{Small Diameter Pipes}

For smaller diameters and thin-wall schedules and interference fits, available cements are called Schedule 40, quick-dry, light-weight cements, or light-body cement. These cements are not designed to fill as much of a gap. They tend to dry faster, do not dissolve into the pipe and fitting as much, and cure somewhat faster. Recommended curing times for various temperature ranges are given in Table 8. Heavy-weight or Schedule 80 cements are used for larger diameters and the heavier-wall schedules of 80 and 120, where the pipe is not roundable. These cements are designed to fill more gap, dry slower, more readily dissolve into the pipe and fitting, and cure somewhat slower. Heavy-weight cements can be and are successfully used in place of the lighter cements. Heavy-weight cements require a longer time to cure. It is extremely difficult to get a satisfactory bonding using lighter and quicker drying cements with larger and heavier-wall pipe. Care should be used to avoid cement spill into the pipe.

The cement should be still wet when the surfaces are mated. A check should be made with the cement supplied to insure it will provide a still-wet surface for at least one full minute with a normal full coat under the actual field conditions. This can be done by preparing a scrap piece of pipe with the primer and then applying a full, even coating with a brush and checking to see if the cement is still wet after one minute.

PVC solvent-cemented joints that are correctly assembled with good cement under reasonable field conditions never blow apart under recommended test pressures when tested after the suggested cure period. Good PVC solvent joints exhibit a complete dull surface on both surfaces when cut in half and pried apart. Leaky joints will show a continuous or an almost continuous series of shiny spots or channels from the socket bottom to the outer lip of the fitting. No bonding occurs at these shiny spots. This condition can increase to the point where almost the entire cemented area is shiny, and fittings can blow off at this point. Shiny areas can be attributed to one or a combination of the following causes:

- Use of a cement which has partially or completely dried prior to installation of the fitting.

- Use of a jelled cement which will not dissolve into the pipe and fitting surfaces due to loss of the prime solvent.

- Insufficient cement or cement applied to only one surface.

- Excess gap which cannot be satisfactorily filled.

- Excess time taken to make the joint after cement was applied. Often in these cases, it is impossible to bottom the fitting since the lubrication effect of the cement has dissipated.

- Cementing with pipe surfaces about $110^{\circ} \mathrm{F}$, resulting in excessive evaporation of prime solvent.

- Cementing when the pipe surfaces are wet or under high humidity and low temperature conditions.

- Joints that have been disturbed and the bond broken prior to a firm set, or readjusted for alignment after bottoming.

- Cementing surface not properly primed and dissolved prior to applying solvent cement.

If the container of cement is subjected to prolonged exposure to air, the cement becomes thick and viscous, or gel-like. This condition is likely due to the evaporation of the solvent. If this occurs, the cement is useless. Do not try to restore the cement by stirring in a thinner. It is suggested that smaller containers of cement be used, especially in warm or hot weather. 
Prior to using an unopened can of cement, it should be shaken vigorously to insure proper dispersion of the resin and solvents. Keep in mind that the solvents contained in PVC cements are highly flammable and should not be used near an open flame. The area in which the cement is being used should be well ventilated, and prolonged breathing of the fumes, as well as contact with the skin or eyes, should be avoided. All PVC cement should be handled in the same manner.

\section{Large Diameter Pipes}

When working with large pipe diameter the basic solvent cement instructions discussed in the last section apply to all sizes of pipe, but when making joints of 4-inch diameter and above, it is recommended that two workers apply the solvent cement simultaneously to pipe and fitting. Additional workers should be in a position to help push the pipe into the fitting socket while the cemented surfaces are still wet and ready for insertion. Alignment of large-diameter pipe and fittings is much more critical than those for the small-diameter pipe. As the pipe diameters increase, the range of tolerances also increases, which can result in "out of round" and "gap" conditions. Reducing the time in making the joint and applications of heavy coats of solvent cement in these cases in important. When working with large pipe diameter ( $\geq 8$ in.), checking the dry fit of pipe and fittings is more critical. In many cases where fabricated fittings are used, interference fits may not be present. Therefore, it will be necessary to apply more than one coat of cement to the pipe and fitting. It is essential to use a heavy-bodied, slow-drying cement on the large-diameter pipes. The heavy cement provides thicker layers and a higher capacity to fill gaps property than regular cement. Heavy cements also allow slightly more open time before assembly.

In installations where belled-end pipe is used to eliminate couplings, it is suggested that the interior surface of the bell be penetrated exceptionally well with the primer. Some manufacturers, in the process of belling pipe, use a silicone release agent on the belling plug, and a residue of this agent can remain inside the bell. This must be removed in the cleaning process.

\section{References}

ASAE. 1998. Design, installation and performance of undergound thermoplastic irrigation pipelines. Standards of American Society of Agricultural Engineering, S376.2. St. Joseph, MI.

Bliesner, R. D. 1987. Designing, operating, and maintaining piping systems using PVC fittings. Irrigation Association, Arlington, VA.

Haman, D. Z. and G. A. Clark. 1995. Fittings and connections for flexible polyethylene pipe used in micro irrigation systems. Univ. of Florida, IFAS, Coop. Exten. Serv. Fact Sheet AE-69.

Jensen, M.E. 1980. Design and operation of farm irrigation systems. ASAE St. Joseph, MI.

Keller, J., D. Karmeli. 1975. Trickle irrigation design. Rain Bird Sprinkler Manufacturing Corporation. Glenora, CA.

Nakayama, F.S., D.A. Bucks. 1986. Trickle irrigation for crop production - design, operation and management. Amsterdam: Elesvier. 
Table 1. Maximum operating pressure for class and SDR-rated PVC pipe.

\begin{tabular}{||c|c||}
\hline \hline Pipe Rating Designation & Maximum Operating Pressure Including Surges \\
\cline { 2 - 2 } & $(\mathrm{psi})$ \\
\hline Class 80 & 80 \\
\hline Class 100 & 100 \\
\hline Class 125 & 125 \\
\hline Class 160 & 160 \\
\hline Class 200 & 200 \\
\hline Class 250 & 250 \\
\hline Class 315 & 315 \\
\hline & \\
\hline SDR 81 & 50 \\
\hline SDR 51 & 75 \\
\hline SDR 41 & 100 \\
\hline SDR 32.5 & 125 \\
\hline SDR 26 & 160 \\
\hline SDR 21 & 200 \\
\hline SDR 17 & 250 \\
\hline SDR 13.5 & 315 \\
\hline & \\
\hline & \\
\hline \hline
\end{tabular}

Table 2. Operating pressures for Schedule 40 and Schedule 80 PVC pipe (Type I, Grade I at $73.4{ }^{\circ} \mathrm{F}$ ).

\begin{tabular}{||c|c|c||}
\hline \hline \multirow{2}{*}{$\begin{array}{c}\text { Diameter } \\
\text { (inches) }\end{array}$} & \multicolumn{2}{|c||}{ Maximum Operating Pressure (psi) } \\
\cline { 2 - 3 } & Schedule 40 & Schedule 80 \\
\hline 3 & 840 & 1200 \\
\hline 4 & 710 & 1040 \\
\hline 6 & 560 & 890 \\
\hline 8 & 500 & 790 \\
\hline 10 & 450 & 750 \\
\hline 12 & 420 & 730 \\
\hline \hline
\end{tabular}

Table 3. Pressure rating service factors for temperatures from 73 to $140^{\circ} \mathrm{F}$ for PVC pipe.

\begin{tabular}{||c|c||}
\hline \hline Temperature $\left({ }^{\circ} \mathrm{F}\right)$ & PVC Factor \\
\hline 73 & 1.00 \\
\hline 80 & 0.88 \\
\hline 90 & 0.75 \\
\hline 100 & 0.62 \\
\hline 110 & 0.50 \\
\hline 120 & 0.40 \\
\hline 130 & 0.30 \\
\hline 140 & 0.22 \\
\hline
\end{tabular}




\begin{tabular}{|c|c|c|c|c|c|c|c|c|c|c|c|c|c|c|}
\hline \multirow{2}{*}{$\begin{array}{l}\infty \\
\infty \\
0 \\
\frac{0}{3} \\
0 \\
\frac{8}{\mathcal{D}} \\
\text { ஸे }\end{array}$} & 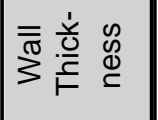 & $\frac{\hat{\sigma}}{\tilde{\sigma}}$ & $\frac{1}{0}$ & $\frac{9}{\frac{R}{0}}$ & $\frac{\bar{\sigma}}{\circ}$ & O̊ & $\stackrel{\infty}{N}$ & 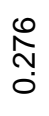 & O্ & 䚙 & $\stackrel{\widetilde{N}}{\stackrel{m}{+}}$ & & & \\
\hline & 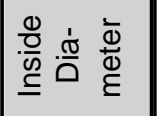 & 点 & 等 & $\begin{array}{l}\hat{\kappa} \\
\text { o } \\
0\end{array}$ & $\stackrel{\infty}{\stackrel{\infty}{N}}$ & 음 & 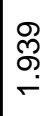 & 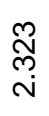 & 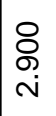 & $\begin{array}{l}\mathscr{0} \\
\infty \\
\infty \\
\infty \\
\end{array}$ & $\begin{array}{l}\bar{c} \\
\stackrel{\circ}{\circ}\end{array}$ & & & \\
\hline \multirow{2}{*}{ 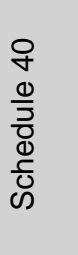 } & 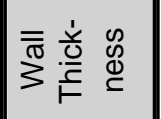 & 竞 & $\frac{m}{5}$ & $\frac{\stackrel{m}{\infty}}{\circ}$ & $\frac{q}{\stackrel{9}{\circ}}$ & $\frac{\text { fo }}{5}$ & $\frac{5}{5}$ & 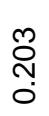 & $\begin{array}{l}0 \\
\\
0\end{array}$ & ָ̂̀ & $\begin{array}{l}\stackrel{8}{0} \\
\stackrel{N}{0} \\
0\end{array}$ & & & \\
\hline & 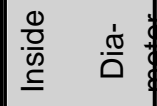 & $\begin{array}{l}\tilde{N} \\
0 \\
0 \\
0\end{array}$ & 离 & 守 & 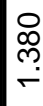 & 음 & $\begin{array}{l}\hat{\theta} \\
\text { ì }\end{array}$ & $\begin{array}{l}\stackrel{8}{6} \\
\stackrel{+}{+}\end{array}$ & $\begin{array}{l}\infty \\
\varnothing \\
\varnothing \\
\dot{\infty}\end{array}$ & $\begin{array}{l}\mathscr{N} \\
\text { Oे } \\
\dot{\forall}\end{array}$ & $\begin{array}{l}10 \\
0 \\
0\end{array}$ & & & \\
\hline \multirow{2}{*}{$\begin{array}{l}\frac{n}{m} \\
\frac{m}{m} \\
\frac{n}{1} \\
0\end{array}$} & 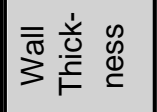 & 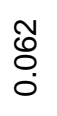 & $\begin{array}{l}\infty \\
0 \\
0 \\
0\end{array}$ & ơ & $\stackrel{\mathscr{N}}{\stackrel{N}{0}}$ & 字 & \begin{tabular}{l}
0 \\
$\stackrel{0}{0}$ \\
\hdashline \\
0
\end{tabular} & 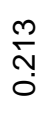 & 总 & ल্ল & 察 & & & \\
\hline & 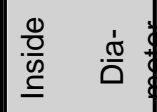 & $\left\{\begin{array}{l}\frac{0}{1} \\
0\end{array}\right.$ & \begin{tabular}{l}
\multirow{2}{*}{} \\
$\infty$ \\
0 \\
0
\end{tabular} & $\stackrel{\bar{N}}{\stackrel{\Gamma}{\leftarrow}}$ & $\frac{i}{\stackrel{8}{+}}$ & $\stackrel{\infty}{\sigma}$ & 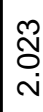 & 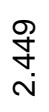 & $\begin{array}{l}\stackrel{\sim}{\infty} \\
\text { o } \\
\text { Ni }\end{array}$ & $\begin{array}{l}\text { W } \\
\infty \\
\infty \\
\text { ल }\end{array}$ & 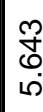 & & & \\
\hline \multirow{2}{*}{ 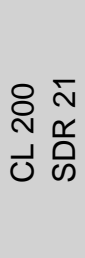 } & 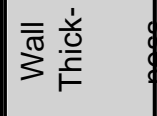 & & $\begin{array}{l}0 \\
0 \\
0\end{array}$ & $\begin{array}{l}\text { ஜृ } \\
0\end{array}$ & $\begin{array}{l}9 \\
\text { T } \\
0 \\
0\end{array}$ & 웅 & $\frac{m}{\frac{m}{0}}$ & $\begin{array}{l}\hat{m} \\
\frac{0}{0}\end{array}$ & $\frac{\hat{\theta}}{\check{0}}$ & 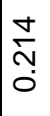 & $\begin{array}{l}0 \\
m \\
0 \\
0\end{array}$ & $\frac{0}{8}$ & ז̊ & $\begin{array}{l}\mathscr{8} \\
\vdots \\
0\end{array}$ \\
\hline & $\stackrel{\frac{0}{0}}{\stackrel{\frac{\pi}{n}}{0}}$ & & Oু & $\begin{array}{l}\stackrel{̊}{\infty} \\
\stackrel{5}{\leftarrow}\end{array}$ & م & 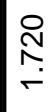 & $\frac{\text { g }}{\stackrel{\text { ì }}{ }}$ & $\begin{array}{l}\bar{\delta} \\
\text { N่ }\end{array}$ & $\frac{\emptyset}{\grave{m}}$ & 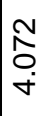 & $\begin{array}{l}\mathscr{m} \\
\text { S. } \\
\text { ம் }\end{array}$ & $\begin{array}{l}L \\
\infty \\
\infty \\
\end{array}$ & $\begin{array}{l}\stackrel{\infty}{N} \\
\text { ஸे }\end{array}$ & 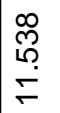 \\
\hline \multirow{2}{*}{ 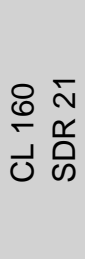 } & $\overline{\bar{\pi}} \frac{\dot{\nu}}{3} \frac{.0}{F}$ & & & \& & ఫ̊ & $\begin{array}{l}\stackrel{n}{\circ} \\
0 \\
0\end{array}$ & Г. & $\frac{0}{\div}$ & $\stackrel{\stackrel{\rho}{m}}{\stackrel{0}{0}}$ & $\frac{m}{\stackrel{N}{0}}$ & $\begin{array}{l}\stackrel{L}{N} \\
\stackrel{N}{0}\end{array}$ & స్ల్ & $\frac{m}{\frac{m}{4}}$ & 导 \\
\hline & $\frac{\mathscr{0}}{\frac{0}{\infty}} \quad \frac{\pi}{\square}$ & & & 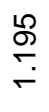 & ָָ & 苫 & 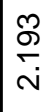 & $\begin{array}{l}i \\
\stackrel{0}{0} \\
0 \\
\text { N }\end{array}$ & 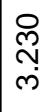 & 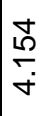 & $\frac{10}{7}$ & 产 & 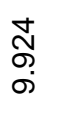 & $\stackrel{\hat{N}}{\stackrel{+}{F}}$ \\
\hline \multirow{2}{*}{ 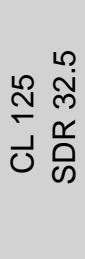 } & 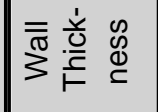 & & & & & & & & $\frac{\infty}{\circ}$ & 衣 & ণ্ণ̣ & 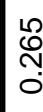 & 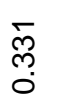 & ळ్ \\
\hline & $\stackrel{\frac{0}{0}}{\stackrel{\omega}{\omega}}$ & & & & & & & & 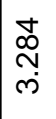 & 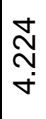 & $\stackrel{N}{N}$ & $\begin{array}{l}\stackrel{L}{\circ} \\
\infty \\
\infty\end{array}$ & $\begin{array}{l}\infty \\
\infty \\
O \\
\circ \\
0\end{array}$ & 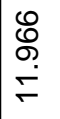 \\
\hline \multirow{2}{*}{ 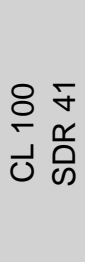 } & $\overline{\bar{\pi}} \frac{\dot{r}}{\frac{\partial}{E}}$ & & & & & & & & & 움 & $\frac{\widetilde{\delta}}{0}$ & 은 & $\begin{array}{l}\text { ָิ } \\
\text { N̦ } \\
0\end{array}$ & $\bar{m}$ \\
\hline & 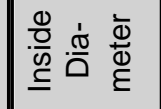 & & & & & & & & & 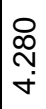 & $\begin{array}{l}\bar{\delta} \\
\text { ల్ } \\
0\end{array}$ & $\underset{\substack{0 \\
\infty}}{\infty}$ & $\begin{array}{l}\stackrel{0}{N} \\
\text { ஸे } \\
\stackrel{0}{0}\end{array}$ & $\begin{array}{l}\stackrel{d}{N} \\
\stackrel{N}{\sim}\end{array}$ \\
\hline \multicolumn{2}{|c|}{ 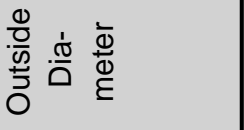 } & $\begin{array}{l}0 \\
0 \\
0 \\
0 \\
0\end{array}$ & 웅 & $\stackrel{n}{m}$ & 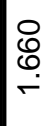 & 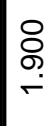 & 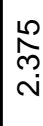 & 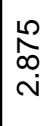 & $\begin{array}{l}8 \\
\text { ட़ } \\
\text { nं }\end{array}$ & 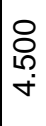 & 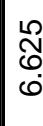 & $\begin{array}{l}\stackrel{1}{0} \\
\infty \\
\infty\end{array}$ & $\begin{array}{l}\stackrel{\circ}{\circ} \\
\stackrel{\circ}{\circ}\end{array}$ & $\stackrel{L}{\wedge}$ \\
\hline 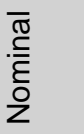 & $\frac{D}{\omega}$ & $=$ & ले & - & $\stackrel{\text { ț }}{r}$ & مִ & $\sim$ & $\stackrel{\sim}{*}$ & $m$ & $\nabla$ & 0 & $\infty$ & 으 & $\stackrel{N}{-}$ \\
\hline
\end{tabular}


Table 5. Minimum depth of cover for buried pipelines.

\begin{tabular}{||c|c|c|c||}
\hline \hline \multirow{2}{*}{$\begin{array}{c}\text { Pipe Size } \\
\text { (inches) }\end{array}$} & \multicolumn{2}{|c|}{ Depth of Cover (inches) } & $\begin{array}{c}\text { Minimum Trench Width } \\
\text { (inches) }\end{array}$ \\
\cline { 2 - 4 } & Traffic Areas & Non-traffic Areas & 6 \\
\hline $1 / 2-11 / 2$ & 18 & 6 & 12 \\
\hline $2-21 / 2$ & 18 & 12 & 16 \\
\hline $3-5$ & 24 & 18 & 18 \\
\hline 6 and larger & 30 & 24 & 6 \\
\hline
\end{tabular}

Table 6. Thrust developed for various fittings per $100 \mathrm{psi}$ of line pressure.

\begin{tabular}{|c|c|c|c||}
\hline \hline $\begin{array}{c}\text { Pipe Size } \\
\text { (in) }\end{array}$ & $\begin{array}{c}90^{\circ} \text { elbow } \\
\text { (lb force) }\end{array}$ & $\begin{array}{c}45^{\circ} \text { elbow } \\
\text { (lb force) }\end{array}$ & $\begin{array}{c}\text { Valves, Tees } \\
\text { (lb force) }\end{array}$ \\
\hline $11 / 2$ & 300 & 200 & 200 \\
\hline 2 & 500 & 300 & 400 \\
\hline 3 & 1000 & 600 & 800 \\
\hline 4 & 1800 & 1100 & 1300 \\
\hline 6 & 4000 & 2300 & 2900 \\
\hline 8 & 7200 & 4100 & 5100 \\
\hline 10 & 11200 & 6300 & 7900 \\
\hline 12 & 16000 & 9100 & 11300 \\
\hline
\end{tabular}

Table 7. Estimated bearing strength of soils.

\begin{tabular}{||l|c||}
\hline \hline \multicolumn{1}{|c|}{ Soil Type } & $\begin{array}{c}\text { Bearing Strength } \\
\left(\mathrm{lb} / \mathrm{ft}^{2}\right)\end{array}$ \\
\hline Muck & 0 \\
\hline Soft clay & 500 \\
\hline Silt loam & 750 \\
\hline Sand & 1000 \\
\hline Sand and gravel & 1500 \\
\hline Sand and gravel with clay & 2000 \\
\hline Sand and gravel cemented with clay & 4000 \\
\hline Hard pan & 5000 \\
\hline \hline
\end{tabular}

Table 8. Recommended joint curing chart for regular and medium bodied cement. Note: heavy bodied cements will require longer curing periods.

\begin{tabular}{||c|c|c|c|c|c|c||}
\hline \hline \multirow{2}{*}{$\begin{array}{c}\text { Temperature } \\
\text { range }\end{array}$} & \multicolumn{2}{|c|}{$1 / 2$ to $11 / 4 \mathrm{inch}$} & \multicolumn{2}{|c|}{$1 / 2$ to $3 \mathrm{inch}$} & \multicolumn{2}{|c||}{$31 / 2$ to 8 inch } \\
\cline { 2 - 7 } & $<180 \mathrm{psi}$ & $180-370 \mathrm{psi}$ & $<180 \mathrm{psi}$ & $180-315 \mathrm{psi}$ & $<180 \mathrm{psi}$ & $180-315 \mathrm{psi}$ \\
\hline $60-100{ }^{\circ} \mathrm{F}$ & $1 \mathrm{hr}$ & $6 \mathrm{hrs}$ & $2 \mathrm{hrs}$ & $12 \mathrm{hrs}$ & $6 \mathrm{hrs}$ & $24 \mathrm{hrs}$ \\
\hline $40-60^{\circ} \mathrm{F}$ & $2 \mathrm{hrs}$ & $12 \mathrm{hrs}$ & $4 \mathrm{hrs}$ & $24 \mathrm{hrs}$ & $12 \mathrm{hrs}$ & $48 \mathrm{hrs}$ \\
\hline $10-40^{\circ} \mathrm{F}$ & $8 \mathrm{hrs}$ & $48 \mathrm{hrs}$ & $16 \mathrm{hrs}$ & $96 \mathrm{hrs}$ & $48 \mathrm{hrs}$ & 8 days \\
\hline \hline
\end{tabular}

